\title{
NEW AMS RADIOCARBON DATES FROM LATE PLEISTOCENE MASTODONS AND MAMMOTHS IN NEW YORK STATE, USA
}

\author{
Robert S Feranec ${ }^{1}$ Andrew L Kozlowski \\ New York State Museum, 3140 Cultural Education Center, Albany, New York 12230, USA.
}

\section{INTRODUCTION}

During the Last Glacial Maximum (LGM) about 25,000 yr ago, the area of what is now New York State (USA) was almost entirely covered by the Laurentide Ice Sheet (LIS; Dyke et al. 2002). Subsequent habitation of this area after the melting of the LIS necessitates dispersal of fauna, and the timing of the dispersal of particular species may aid in the understanding of how the modern ecosystems of New York were assembled. Mastodons and mammoths represent the most abundant postLGM Pleistocene megafauna recovered in New York. However, many of the specimens have not been dated. This paper presents a set of dates from bone and tooth dentine collagen of late Pleistocene mastodon $(n=7)$ and mammoth $(n=3)$ specimens housed in the Vertebrate Paleontology Collections at the New York State Museum, Albany, New York, USA.

To extract collagen, preparation procedures generally follow Brown et al. (1988) and Bronk Ramsey et al. (2004). Most samples were untreated or samples were taken from untreated areas (e.g. within enamel tooth plates). Two samples appear to have been treated with consolidant (NYSM VP-49 Ellenville Mastodon; NYSM VP-54 Pirrello Mastodon). These samples were washed several times with $100 \%$ ethanol followed by distilled water, and dried prior to decalcification. Samples were decalcified using $0.5 \mathrm{~N} \mathrm{HCl}$ to obtain collagen, typically over $24 \mathrm{hr}$. Once decalcified, collagen was then gelatinized at $58{ }^{\circ} \mathrm{C}$ for $17 \mathrm{hr}$. Subsequently, the gelatin solution was filtered to remove any remaining solids, and then ultrafiltered to remove the $30-\mathrm{kD}$ fraction, which was then lyophilized. In general, lyophilized collagen appeared similar to a white cotton ball. Graphitization and analysis were conducted at the National Oceanic Sciences Accelerator Mass Spectrometry (NOSAMS) facility (Woods Hole, Massachusetts, USA). All dates were calibrated using the online CALIB 6.0html program (Stuiver et al. 2005). The calibrated dates reported below represent the $2 \sigma$ age range, and were rounded to the nearest $50 \mathrm{yr}$.

\section{RESULTS}

\section{Mammoths}

NYSM VP-26: Mammoth, Mammuthus sp. (Madison County, New York)

NOSAMS OS-93430. Chittenango Mammoth

$$
\begin{array}{r}
11,250 \pm 65 \mathrm{BP} \\
\delta^{13} \mathrm{C}=-\mathbf{2 0 . 6 5 \%}
\end{array}
$$

Tusk collagen. New York State Museum Vertebrate Paleontology Locality: VPL-21; 12,950-13,300 cal BP.

Comments: Originally discovered during construction of the Erie Canal in 1825 (Hartnagel and Bishop 1922), many pieces of this specimen were removed by private collectors upon discovery. At present, the New York State Museum possesses 1 piece of tusk as well as a portion of the lower jaw including the mandibular symphysis.

\footnotetext{
${ }^{1}$ Corresponding author. Email: rferanec@mail.nysed.gov.
} 
NYSM VP-32: Woolly mammoth, Mammuthus primigenius (Wayne County, New York) NOSAMS OS-85534. Clyde Barge Canal Mammoth

$$
\begin{array}{r}
11,750 \pm 65 \mathrm{BP} \\
\delta^{13} \mathrm{C}=-20.21 \%
\end{array}
$$

Tooth dentine collagen. New York State Museum Vertebrate Paleontology Locality: VPL-25; $13,400-13,750$ cal BP.

Comments: In 1910, a tooth was discovered 2.5 miles east of Clyde, New York, during construction of Lock 26 of the New York State barge canal at a depth of 22 feet. The specimen was found sitting on a layer of gravel within a layer of sand and clay (Hartnagel and Bishop 1922).

NYSM VP-95: Woolly mammoth, Mammuthus primigenius (Cattaraugus County, New York)

\section{NOSAMS OS-93354. Randolph Mammoth}

$10,350 \pm 45 \mathrm{BP}$ $\delta^{13} \mathrm{C}=-17.58 \%$

Tooth dentine collagen. New York State Museum Vertebrate Paleontology Locality: VPL-75; $12,050-12,400$ cal BP.

Comments: In May 1934, this specimen was discovered during expansion of the East Randolph Fish Hatchery, Randolph, New York. This specimen was recovered from layers of blue clay and overlying marl at a depth of about $250 \mathrm{~cm}$. At present, this individual represents the most complete woolly mammoth skeleton found in New York State and consists of the skull, 2 tusks, the left lower third molar, and distal portions of the right ulna, right radius, and left femur.

\section{Mastodons}

\section{NYSM VP-49: American mastodon, Mammut americanum (Ulster County, New York)}

\section{NOSAMS OS-94876. Ellenville Mastodon

Bone collagen from skull fragment. New York State Museum Vertebrate Paleontology Locality: VPL-6; 12,600-12,900 cal BP.

Comments: Likely discovered in 1859, the remains of this mastodon skeleton were received by the New York State Museum in 1860. The bones were found in McElhone's Pond near Church Street in Ellenville in a marl layer that was between 61 and $152 \mathrm{~cm}$ deep. This individual appears to have been particularly old, noted by the last molars (i.e. $\mathrm{M}^{3}$ ) being worn through the dentine into the pulp cavities (Hartnagel and Bishop 1922).

\section{NYSM VP-54: American mastodon, Mammut americanum (Steuben County, New York)}

\section{NOSAMS OS-93357. Perkinsville Mastodon}

$11,500 \pm 45 \mathrm{BP}$ $\delta^{13} \mathrm{C}=-\mathbf{2 0 . 9 5 \%}$

Tooth dentine collagen. New York State Museum Vertebrate Paleontology Locality: VPL-1; 13,250 13,450 cal BP.

Comments: The remains of this American mastodon individual were discovered in August 1907 near Perkinsville, New York (Hartnagel and Bishop 1922). The excavation recovered a majority of the bones of the 4 legs and feet, as well as the ribs and vertebrae. Bones were likely deposited in a marl unit at a depth greater than $31 \mathrm{~cm}$. 
NYSM VP-93: American mastodon, Mammut americanum (Wayne County, New York)

NOSAMS OS-93338. Pirrello Mastodon

$11,700 \pm 40 \mathrm{BP}$

$\delta^{13} \mathrm{C}=-\mathbf{2 0 . 5 3 \%}$

Bone collagen from rib fragment. New York State Museum Vertebrate Paleontology Locality: VPL$67 ; 13,400-13,700$ cal BP.

Comments: This specimen was previously identified with NYSM Accession number 29668. Discovered in 1973, this specimen was recovered about 7 miles north of Newark, New York, on the Pirrello Celery Farm (Thomson et al. 2008). The bones were uncovered about $75 \mathrm{~cm}$ below the surface in a gray marl layer that was underlain by a layer of fine sand. The specimen consists of about 40 bones, primarily vertebrae and bones of the left foot. Material was previously carbon dated to $10,340 \pm$ 170 BP (Reilly 1974; 11,400-12,600 cal BP). The $2 \sigma$ calibrated age range of this current date does not overlap with the older date. We suspect that this is due to new bone preparation and collagen extraction techniques as well as new dating technologies, such as AMS.

\section{NYSM VP-94: American mastodon, Mammut americanum (Orange County, New York)}

NOSAMS OS-78281. Tunkamoose Mastodon Tusk A

$$
\begin{array}{r}
12,350 \pm 65 \mathrm{BP} \\
\delta^{13} \mathrm{C}=-19.32 \%
\end{array}
$$

Tusk collagen. New York State Museum Vertebrate Paleontology Locality: VPL-76; 14,050-14,900 cal BP.

NOSAMS OS-78282. Tunkamoose Mastodon Tusk B

$12,300 \pm 45 \mathrm{BP}$

$\delta^{13} \mathrm{C}=-19.62 \%$

Tusk collagen. New York State Museum Vertebrate Paleontology Locality: VPL-76; 14,000-14,850 cal BP.

Comments: Initially discovered in the fall of 2008, 2 tusks were recovered in July 2009 along the Wallkill River about 2.25 miles southeast of the junction of New York State Route 284 and County Road \#1 in Westtown, New York. The tusks were recovered from a marl layer at a depth of $\sim 155 \mathrm{~cm}$.

NYSM VP-100: American mastodon, Mammut americanum (Orange County, New York)

NOSAMS OS-93337. Temple Hill Mastodon $\quad 10,900 \pm 40$ BP $\delta^{13} \mathrm{C}=-\mathbf{2 0 . 3 9 \%}$

Tooth dentine collagen. New York State Museum Vertebrate Paleontology Locality: VPL-8; 12,65012,900 cal BP.

Comments: Discovered in 1921, this specimen was found one-half mile west of Temple Hill Monument and 1 mile north of Vails Gate Junction, New York. The skeleton is large and nearly complete. This specimen was found within a few hundred feet of another mastodon recovered in 1917 (Hartnagel and Bishop 1922). The scapula of NYSM VP-100, Temple Hill Mastodon, was previously dated to $11,000 \pm 80 \mathrm{BP}$ (NZA 12584; 12,700-13,100 cal BP; Robinson et al. 2005). The $2 \sigma$ calibrated age range of this current date falls within the calibrated range previously obtained.

NYSM VP-102: American mastodon, Mammut americanum (Orange County, New York)

NOSAMS OS-93884. Arborio Mastodon

$11,750 \pm 60 \mathrm{BP}$

$\delta^{13} \mathrm{C}=-\mathbf{2 1 . 1 5 \%}$

Tooth dentine collagen. New York State Museum Vertebrate Paleontology Locality: VPL-16; $13,400-13,750$ cal BP. 
Comments: In 1968, this specimen was discovered during construction of US Interstate 84 within the village of Montgomery in Orange County, New York (Thomson et al. 2008). The specimen was recovered from a layer of marl at an unknown depth. A significant portion of the skeleton was found including portions of the skull, fragments of both upper tusks, mandible, vertebrae, ribs, left and right scapula, left and right humerus, left and right ulna, left radius, left and right innominate, right femur, right tibia, right patella, lunar, scaphoid, cuboid, metacarpals 2 and 3, and 2 phalanges (Thomson et al. 2008). A rib of this specimen was previously dated to $10,000 \pm 160 \mathrm{BP}$ (I-3785; $11,150-12,150$ cal BP; Funk et al. 1970). The $2 \sigma$ calibrated age range of this current date does not overlap with the older date. We suspect that this is due to new bone preparation and collagen extraction techniques as well as new dating technologies, such as AMS.

\section{DISCUSSION}

The dates for the mastodon and mammoth specimens presented here range between about 12,000$15,000 \mathrm{cal}$ BP. This implies about 10,000 yr from the height of the LGM to dispersal of these specimens into the area that is now New York State. While there are ecological differences between mastodons and mammoths, these species appear to have been contemporaneous in the state, as supported by the dates of the Clyde Barge Canal Mammoth (NYSM VP-32) and Pirrello Mastodon (NYSM VP-93) from Wayne County, New York (Figure 1), which may indicate heterogeneous habitats present on the landscape at this time in the late Pleistocene. The dates from the Tunkamoose Mastodon (NYSM VP-94) are currently the oldest American mastodon dates known from the state (Thomson et al. 2008), while the dates from the Randolph Mammoth (NYSM VP-95) are currently the most recent for woolly mammoth from New York.

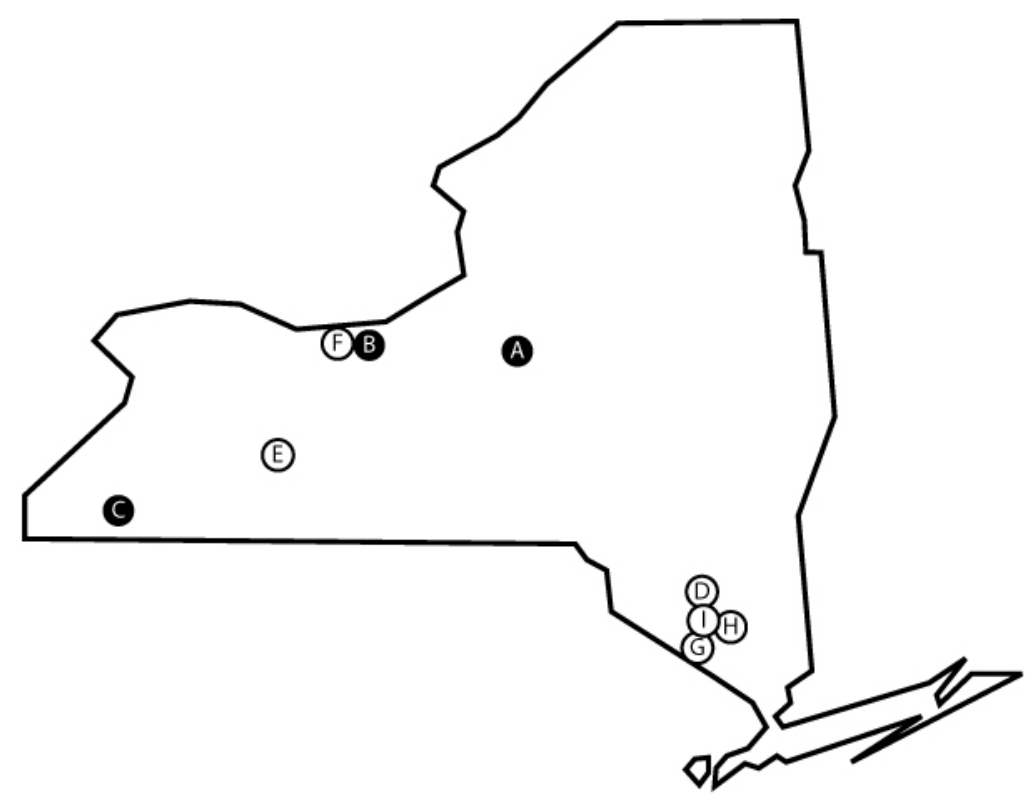

Figure 1 Map of localities of specimens included in this study. Closed circles, mammoths; open circles, mastodons. A, NYSM VP-26, Chittenango Mammoth; B, NYSM VP-32, Clyde Barge Canal Mammoth; C, NYSM VP-95, Randolph Mammoth; D, NYSM VP-49, Ellenville Mastodon; E, NYSM VP-54, Perkinsville Mastodon; F, NYSM VP-93, Pirrello Mastodon; G, NYSM VP-94, Tunkamoose Mastodon Tusk A \& Tusk B; H, NYSM VP-100, Temple Hill Mastodon; I, NYSM VP-102, Arborio Mastodon. 


\section{ACKNOWLEDGMENTS}

We would like to thank L Lain, Gl Keeton, Ga Keeton, C Connallon, J Greiner, H R Decker, J Lothrop, G Malin, N Krumdieck, M Younge, and P Stefanik for their help in the recovery of the Tunkamoose Mastodon tusks. We thank 2 anonymous reviewers for comments that benefited this manuscript. We also thank K Elder and S Handwork for help in the sample analysis at NOSAMS. Funding was provided by an New York State Museum Research grant to RSF, and a USGS Statemap grant to ALK.

\section{REFERENCES}

Bronk Ramsey C, Higham T, Bowles A, Hedges R. 2004. Improvements to the pretreatment of bone at Oxford. Radiocarbon 46(1):155-63.

Brown TA, Nelson DE, Vogel JS, Southon JR. 1988. Improved collagen extraction by modified Longin method. Radiocarbon 30(2):171-7.

Dyke AS, Andrews JT, Clark PU, England JH, Miller GH, Shaw J, Veillette JJ. 2002. The Laurentide and Innuitian ice sheets during the Last Glacial Maximum. Quaternary Science Reviews 21(1-3):9-31.

Funk RE, Fisher DW, Reilly Jr EM. 1970. Caribou and paleo-indian in New York State: a presumed association. American Journal of Science 268(2):181-6.

Hartnagel CA, Bishop SC. 1922. The mastodons, mam- moths and other Pleistocene mammals of New York State. New York State Museum Bulletin Nos. 241-242. Reilly EM. 1974. New York elephant hunt. The Conservationist 28(6):5-7, 47.

Robinson GM, Burney DA, Burney LP. 2005. Landscape paleoecology and megafaunal extinction in southeast New York State. Ecological Monographs 75:295-15.

Stuiver M, Reimer PJ, Reimer RW. 2005. CALIB 6.0html. URL: http://calib.qub.ac.uk/calib/. Accessed 7 April 2012.

Thomson LM, McIntosh GC, Allmon WD. 2008. Discoveries of the American mastodon (Mammut americanum) in New York State: 1922-2007. Paleontographica Americana 61:25-41. 